University of Wollongong

Research Online

Faculty of Law, Humanities and the Arts Papers (Archive)

Faculty of Arts, Social Sciences \& Humanities

$1-1-2018$

Shahrazad in Cronulla: David Foster's Retelling of One Thousand and One Nights in Sons of the Rumour

Farzaneh Mayabadi

University of Wollongong, fm676@uowmail.edu.au

Wenche Ommundsen

University of Wollongong, wenche@uow.edu.au

Follow this and additional works at: https://ro.uow.edu.au/lhapapers

Part of the Arts and Humanities Commons, and the Law Commons

Research Online is the open access institutional repository for the University of Wollongong. For further information contact the UOW Library: research-pubs@uow.edu.au 


\title{
Shahrazad in Cronulla: David Foster's Retelling of One Thousand and One Nights in Sons of the Rumour
}

\begin{abstract}
This reading of David Foster's Sons of the Rumour focuses on its frame story, a reworking of the frame story of One Thousand and One Nights. It provides an overview of the impact of One Thousand and One Nights on world literature and goes on to analyse how Foster reimagines One Thousand and One Nights in order to illustrate humanity's struggle between the spiritual and the material world. Foster constructs a parallel dilemma for Al Morrisey, a secular Australian Jew, and the Shah, a Persian Muslim. Differences between them favours Al's secularism over the Shah's Islamic faith, and tends to harden and exaggerate stereotypes, following a typical Orientalist pattern by recreating the structure of One Thousand and One Nights for a Western understanding of and taste for Orientalist material.
\end{abstract}

\section{Keywords}

sons, rumour, david, foster's, shahrazad, retelling, cronulla:, one, thousand, nights

\section{Disciplines}

Arts and Humanities | Law

\section{Publication Details}

Mayabadi, F. \& Ommundsen, W. "Shahrazad in Cronulla: David Foster's Retelling of One Thousand and One Nights in Sons of the Rumour." Journal of Intercultural Studies 39.5 (2018): 570-580. 


\title{
Shahrazad in Cronulla:
}

\section{David Foster's Retelling of One Thousand and One Nights}

\author{
in Sons of the Rumour
}

\section{Farzaneh Mayabadi and Wenche Ommundsen}

\begin{abstract}
This reading of David Foster's Sons of the Rumour focuses on its frame story, a reworking of the frame story of One Thousand and One Nights. It provides an overview of the impact of One Thousand and One Nights on world literature and goes on to analyse how Foster reimagines One Thousand and One Nights in order to illustrate humanity's struggle between the spiritual and the material world. Foster constructs a parallel dilemma for Al Morrisey, a secular Australian Jew, and the Shah, a Persian Muslim. Differences between them favours Al's secularism over the Shah's Islamic faith, and tends to harden and exaggerate stereotypes, following a typical Orientalist pattern by recreating the structure of One Thousand and One Nights for a Western understanding of and taste for Orientalist material.
\end{abstract}

Keywords: One Thousand and One Nights; Orientalist feminism; Islamophobia; the Cronulla riot 
One Thousand and One Nights is considered a major masterpiece of world literature. The collection of tales has had a remarkable influence on English literature and a great impact on the West's understanding of the Orient. Ulrich Marzolph writes that after the Bible, only One Thousand and One Nights 'has had such a long-lasting and deep impact on world culture.' (2006a: 3) David Foster's 2009 novel Sons of the Rumour is one in a long line of literary texts which take their inspiration from the Nights' exotic themes and intricate structure. Drawing on the work of Edward Said and other postcolonial theorists, this paper traces parallels between One Thousand and One Nights and Foster's novel in order to establish the effects, cultural and ideological, of this rewriting for a $21^{\text {st }}$ century Australian readership. We argue that by turning this pre-Islamic story cycle into an argument in contemporary debates about gender and religion, and beyond that, about the clash of cultures which has seen Islam demonised as a religion not only of misogyny but also of terror, Sons of the Rumour perpetuates some of the orientalist stereotypes which have accompanied the West's fascination with the Nights since the beginning of the $18^{\text {th }}$ century.

Sons of the Rumour is a novel of immense complexity. Its loose adaptation of the structure of One Thousand and One Nights sees the story of Shahrazad and the Shah framing a number of seemingly unrelated tales told not by Shahrazad but by members of a Sufi fraternity called the Sons of the Rumour. These stories, based on considerable erudition as well as great flights of fancy, take the reader on a romp through exotic locations, different belief systems and exquisite accounts of suffering, all illustrating the human quest for meaning and the seeming absurdity of all religions. Our analysis focuses exclusively on the frame narrative, which at one point, rather mysteriously, morphs into a contemporary Australian story, and we thus make no claim to account for the postmodern complexity of the novel as a whole. Our aim is to trace the dichotomy it establishes between East and West, particularly in relation to gender and sexuality. When the Australian story zooms in on a particular event, the Cronulla riots, and on another 
contrast, between Islam and Western secularism, we argue that the novel echoes the slippage between race and religion that has characterised much of the post-9/11 commentary linking the Middle East, Islam and terrorism, and by so doing contributes to the us-and-them discourse that blights communication between mainstream and minority communities in Western nations.

\section{One Thousand and One Nights in World Literature}

The West came to know One Thousand and One Nights primarily through its translation into French by Antoine Galland at the beginning of the eighteenth century (published gradually from 1704, translated into English and other languages during the eighteenth century), although, because of the folkloric origin of the tales, there had been 'a reflected gleam of the Nights in Western literature' (Pellat 1985) in earlier centuries. Since then, the tales have had a revolutionary impact on literature, theatre, opera, music, painting and architecture up until our own time. Nourjahad (1767) by Frances Sheridan, New Arabian Nights (1882) by Robert Louis Stevenson, Midnight's Children (1981) by Salman Rushdie and the latter's most recent work, Two Years Eight Months and Twenty-Eight Nights (2015) are all examples of texts directly influenced by One Thousand and One Nights (see Irwin 2009). Edgar Allan Poe, Charles Dickens, Matthew Arnold, Alfred Lord Tennyson, Edward FitzGerald, Marcel Proust and James Joyce are only some of the writers who have been inspired by this collection.

In contrast to the huge impact and enduring popularity of One Thousand and One Nights in the West, The Nights is not popular in its place of origin, Iran. Marzolph speculates on the reason for this:

The consumption of alcoholic beverages and the indulging in extramarital sexual relations, both of which are frequently encountered in the Nights, contradict the moral values presently propagated in Iran, and publishers opt for different strategies to adjust the text so as to eliminate reprehensible components.... Whereas the Western world has grown accustomed to regarding the Nights as a monumental and uninhibited affirmation of the 
joy of life in all its manifestations, Iranian readers are restricted to textual versions that have been adapted to their present political circumstances. (2004: 289-290)

One Thousand and One Nights has Iranian, Indian and Arabic origins, and its history is often poorly understood. The most ancient version, titled Hazar Afsan, dates to pre-Islamic times when the Achaemenid Empire ruled Persia, and is believed to go back to Indian origins (Marzolph 2004: 275). In the eighth or early ninth century, the Persian Hazar Afsan was translated into Arabic and was given the Arabic title Alf Khurafa before being retitled Alf Layla (A Thousand Nights). However, despite being commonly known as the 'Arabian Nights', the majority of the tales, including the frame tale, as Jiri Cejpek points out, are undoubtedly of IndoPersian origin, though some tales were added, along with Arabic and Islamic cultural inflections, over the centuries (cited in Marzolph 2004: 278). After the collection was introduced to the West, it was formed into its present version 'by European demand and influence'. 'In this manner', Marzolph argues, this collection 'has not only shaped the West's perception of the 'Orient' as the quintessential 'Other' but has also contributed decisively to developing and channelling creative imagination in virtually all areas of human activity' (2006b: vii). At first, it was regarded purely as entertainment, then, writes Irwin, 'the serious study of the Nights coincided with the development of orientalism as an academic discipline' in the early decades of the nineteenth century (2009: 42-43). Or, as Marzolph puts it, 'the equally collective fascination of the West with the Oriental Other played an important role' in its attractiveness. Marzolph adds that what Galland did was appropriate rather than translate the text for the eighteenth century reader (2006a: 4). Edward Said, in his path-breaking work on Orientalism, uses the example of Silvestre de Sacy to criticise the belief that the presence of the Orientalist scholar was necessary for Arabic poetry to be appreciated. What Galland did to The Nights is similar to Sacy's approach to the selection of Arabic poems in his Chrestomathie Arabe (1806), in which he adapts this work for a French readership. Sacy, a $19^{\text {th }}$ century French Orientalist, 
was 'the teacher of nearly every major Orientalist in Europe' (Said 2003: 183). Said argues that Sacy's 'work is essentially compilatory; it is thus ceremoniously didactic and painstakingly revisionist' (2003: 126). Sacy believed that Oriental writings, with their superstitions and prejudices, could only be understood by Europeans 'after long and painful study', and were totally strange to Europeans 'who have attained to a higher degree of civilisation' (Said 2003: 128). Sacy also argued that by themselves, these texts did not contain 'enough interest', or 'taste and critical spirit' to be worthy of publication (Said 2003: 128). As a consequence, it was necessary for Orientalists to transform Oriental writings by using 'a series of representative fragments, fragments republished, explicated, annotated, and surrounded with still more fragments' (Said 2003: 129). This was arguably the thinking, and the methodology, that inspired the translation of all Oriental texts, including One Thousand and One Nights, for European readers. Interestingly, as Charles Pellat argues, apart from some of the embedded tales which have been used by novelists, writers and poets, it is the frame story of One Thousand and One Nights that has had by far the greatest impact on Western culture

and through it on contemporary Arabic literature, which has sought in it a source of inspiration truly Arabic, even though the protagonists bear Persian names. Such exploitation is an indirect tribute to the Indo-Persian storytellers who provided the foundation for a monument long disdained by the Arabs and then revealed to the world by a West that has not yet finished taking delight in it. (1985)

In regard to the influence of One Thousand and One Nights on world literature, Al-Olaqi argues that 'the Arabian Nights combines the knowledge of the Oriental culture and artistic luxuriance with dramatic, gothic and ironic elements which eventually help any English writer to produce a work that suits his own formula' (2012: 394). Rana Kabbani, in Imperial Fictions: Europe's Myths of Orient writes: 
In the European narration of the Orient, there was a deliberate stress on those qualities that made the East different from the West, exiled it into an irretrievable state of 'otherness'. Among the many themes that emerge from the European narration of the Other, two appear most strikingly. The first is the insistent claim that the East was a place of lascivious sensuality, and the second that it was a realm characterised by inherited violence. (1994: 5-6)

This is, of course, precisely Said's argument in Orientalism. Our reading of a novel published in Australia in 2009 examines how, and to what extent, the themes that attracted early scholars and readers to the Nights have survived into a rewriting of this Orientalist classic for the $21^{\text {st }}$ century.

\section{Sons of the Rumour}

Sons of the Rumour (2009) by David Foster is an extraordinarily complex novel the main concern of which is the human quest for happiness and enlightenment through spirituality and religion while humanity is bound, through the body and in particular through sexual desire, to the physical world. The novel has an intricate plot, adopting the frame and embedded storystructure of One Thousand and One Nights. The frame story is a version of the story of Shahrban, king (Shah) of Persia, and his wife Shahrazad (Sheherazade in most translations) with its focus on jealous husbands and adulterous wives. In One Thousand and One Nights, Shahrban is so enraged by his first wife's infidelity that he takes revenge on all women, marrying a virgin every day and beheading her the following morning. Shahrazad, the Wazir's daughter, voluntarily marries the Shah, and then recruits her sister, Dinazad, to ask her to tell a story at night. The Shah listens, spellbound, to Shahrazad's story, and when she stops in the middle, grants her request to spare her life for one more day so she can finish the tale. This scenario is repeated night after night until the Shah falls in love with her and abandons his murderous plot. In Sons of the Rumour, this frame story is called 'Iranian Days'. It is also interspersed by other stories, in this case not told by Shahrazad, but by members of a Sufi 
fraternity, the Sons of the Rumour. These stories, with their intricate plots and extravagant settings are all, in the words of Susan Lever, aimed at 'educating the murderous, misogynistic Shah in the possibilities for spiritual life and the fatal nature of sexual desire' (2013: 88). The story of the Shah and his rebellious wife mysteriously merges with the contemporary Australian story of Al Morrisey, fleeing to Ireland after the break-up of his marriage to his adulterous wife Pastel. It then concludes on the Shah's miraculous conversion to a more enlightened view of gender relations.

While the frame story echoes that of One Thousand and One Nights there are important differences relating to the main characters and their motivation. In the original, the Shah is represented as selfish and naïve, beheading virgins to protect his honour. In Sons of the Rumour he is cruel, obsessed with sex, diabolical even. He beheads virgins to do God's justice and delays murdering Shahrazad because of her sexual attributes, also because she claims to be pregnant. He has no interest in Shahrazad's tales, preferring those of the Sufi masters. His conversion comes as the result of the spiritual education he receives from the embedded tales, as well as the revelations that come to him through his dream of $\mathrm{Al}$.

The transformation of Shahrazad is even more startling. In One Thousand and One Nights, she is represented as a virtuous and wise woman, a selfless character who, through her stories, finds a way to save and protect the lives of other women. Shahrazad thus stands in sharp contrast to the women in her tales, often portrayed as being without self-control, regularly betraying their husbands. The Shahrazad of Sons of the Rumour is represented as a Western woman, blonde and blue-eyed, with modern attitudes and a marvellously vulgar (and Australian-accented) language to match. Shahrazad and Pastel, Al's wife, are both sexually confident, and the Shah and Al are both anxious about their masculinity and deeply troubled by their wives' sexual adventures. The novel refers to both Shahrazad and Pastel using the term 
'elephant', a symbol of sexual licence and disloyalty, at the same time as it signals power and wisdom.

The storytellers who give the novel its title have no match in One Thousand and One Nights. The Sons of the Rumour are also known by the name Pir, a title for Sufi masters devoted to finding the inner dimension and path of Islam. The Sons of the Rumour perform spiritual practices in the Khangah, where the Shah visits daily, seeking their guidance in his quest for happiness and enlightenment - and to keep his mind off Shahrazad and his sexual desires (2009: 7). Their tales, though based on extensive research, are clearly a product of Foster's imagination, and not, even within the frame narrative, presented as factual: 'while Rumour remains more powerful than Truth, we are Sons of the Rumour' (Foster 2009: 5). While the Shah is desperately looking for happiness and enlightenment to release himself from 'his monstrous jealousy, [and] his masculine self-doubt' (Sornig 2009: 29), the tales offered by the Sons suggest that his quest may be pointless and that he should seek alternative routes. As one of the Sons puts it, 'it is not a case of, 'Do this, that or the other and you will achieve Happiness', but rather 'Achieve Happiness and you will find yourself doing, instinctively, this, that or the other', (2009: 37).

The novel's two main plotlines are intertwined. 'Iranian Days' is set in the early ninth century AD, and Al's story in present-day Australia. The ninth-century Shah faints while visiting the Mosque in Cordoba, Spain, and has a dream, which turns into the story of $\mathrm{Al}$ Morrisey. Through Al's stream of consciousness, we learn about his life, his trouble with women (his elderly demented mother, his wife), about the Cronulla riots, which he witnessed before leaving Australia, and about his dreams. Al has been reading 'voraciously, over the past decade, of Central Asia with its religious pammixia' and is now suffering from nightmares about all things Persian (2009: 286-7). As the story of Al is happening in the Shah's dreamworld, and vice versa, the Shah and Al must at one level be regarded as the same character, 
their fates closely inter-connected. Susan Lever has pointed out that Al is also 'clearly a version of Foster himself, a musician and small farmer' (2013: 95). Within the exotic locations, deliberate anachronisms and convoluted story-lines of Sons of the Rumour we find a world that is at the same time distant and close, read through a cultural lens that is recognisably of our own time.

\section{Misogyny Eastern and Western}

Through its multiple and entangled plotlines, Sons of the Rumour demonstrates the absurdity of all religions - Islam, Judaism, Christianity, even Taoism - as spiritual guides to human happiness. These belief systems, and Islam and Christianity in particular, are also shown to be hostile towards women. The portrayal of the Shah and Al (a secular Jew), and the parallels between them, focus on their misogyny, their fear and loathing of, and their helpless dependence on, the women in their lives. However, not all misogynies are equal, so alongside the parallels and similarities between $\mathrm{Al}$ and the Shah, there are differences between them which stereotype Muslims and imply a more redeemable position for Western man, and for post-Christian Western society. The frame story of One Thousand and One Nights arguably stands as the literary prototype for misogynistic behaviour, and this particular rewriting of the tale, with its emphasis on the Shah's religious motivations and on Western agency in his redemption, turns the pre-Islamic story into an argument in contemporary debates about gender and religion, rehearsing familiar ideas about the sexism inherent in Islam and Islamic culture.

Foster's Shah, like his counterpart Al, is not only obsessed by women's bodies, but admits to being a hopeless romantic. When the Pir asks if he is a misogynist, he replies, ' $[\mathrm{t}] \mathrm{o}$ the contrary... I adore them. I'm the complete romantic' (2009: 177). On another occasion he says, 'I am earth for her treading and dust to her sandals. My vitals are consumed. My love for her is mingled with my flesh and with my blood and has entered into the channels of my bones' 
(2009: 133). At the same time, he is in no doubt that this love has to be based on male domination, as justified by his religion: '[b]ecause Allah has made the man superior to the woman' (2009: 126). Similarly, Al believes that 'men should be in charge of women' (2009: 291), though his justification is not religious but rather a vague sense that this is in the 'natural' order of things. R. Howard Bloch in Medieval Misogyny and The Invention of Western Romantic Love explains this co-existence of woman hatred, male possessiveness and romantic love as a product of medieval misogyny:

\footnotetext{
The coming into being of Western romantic love was part of a particular moment in the history of misogyny - a moment at which, because of contemporaneous changes in both the forms of property and relations of power between the genders, the debilitating obsession with woman as the source of all evil became inverted into a coconspiring obsession with woman as the source of all good. (1991: 11)
}

Both the Shah and $\mathrm{Al}$ fear and love women in equal measure, are obsessed with them as objects of sexual attraction, want to own them and treat them as their concubine and regard their wives' betrayal as a threat to their masculinity. As Judith Kegan Gardiner argues,

\footnotetext{
Men's feelings of possession and entitlement reach a negative extreme against wives and girlfriends who leave or reject them. Even honour killings, in which men murder wives, daughters or sisters for alleged unchastity, can be seen as partly springing from feelings that the beloved is the property of the lover, her behaviour reflecting on his, so that he would rather destroy her than allow another man to possess her. (2007: 370)
}

Romantic love becomes a strategy to convince 'free women to become subordinated wives' (Gardiner 2007: 370). The Shah's murderous campaign thus finds its parallel in Al's (and his own) romantic posturing; both, however, are thwarted by their rebellious wives' challenge to their authority. 
There are also important differences between $\mathrm{Al}$ and the Shah. At the end of his marriage, $\mathrm{Al}$ is contrite, acknowledging that he may himself be responsible for her infidelity: 'you have, perhaps, ill-treated Pastel, to get out of the marriage?' (2009: 308) Al calls himself 'a failed womaniser' (2009: 309) and, unlike the Shah, decides to stay alone rather than look for revenge after Pastel's infidelity: 'I guess I love you enough that I want you to have what you want to have for yourself, Pastel' (2009: 304). By contrast the Shah, in Sons of the Rumour, is even more barbarous and lustful than his counterpart in One Thousand and One Nights. His own subjects criticise him as 'a Poisonous Dragon who feasts each night on a fresh virgin, destined on the morrow for the scaffold' (2009: 169), and the narrator calls him 'the Beast of Merv' (2009: 70,169). One of the Sons of the Rumour tells him '[y]our mistake was in falling in love with a woman like a god and then behaving like a beast' (2009: 73). Not only is he brutal towards women, he is also, as both the Sons of the Rumour and Shahrazad point out, incapable of governing his country. His inadequacy as a man, a lover and a ruler comes to a head when he travels to Cordoba to speak at a conference (anachronistically) entitled 'Silk Road: Implications for Future Umayyad Policy Directions' (2009: 250). He initially has no idea what the Silk Road is, thinking that it is, literally, a road made out of silk. His speech at the conference is confused and confusing: he soon stops talking about silk altogether, moving on 'to a confession of his distrust for women' (2009: 275), finally bursting into tears (2009: 276). His subsequent humiliation is complete: his accent is ridiculed, his servants make off with his money and he is reduced to begging for bread. Rescued from certain death by divine intervention, the Shah heads to the Mosque, where he sustains the head injury which leads to his vision of Al. On awakening he seems a changed man, not only restored to his former status, but also 'cured' of misogyny. On his return to Merv he summons Shahrazad and Dinazad and delivers the following speech: 
Good morning, ladies. I have a dream. In this dream I see many women all but naked but don't get the wrong idea. They are unmolested and freed of the tyranny of kinsmen, working as Wazirs, Qadis and mirabs. I see them holding chairs in universities, becoming firemen, bishops and rabbis, dressing entirely to suit themselves, living alone if they so desire, divorcing their husbands if and when they choose. I see them in command of their own destinies, drinking alcohol, eating bhang, smoking opium and ephedra, walking the streets at night unaccompanied, conversing with young men never before seen while laying about stark naked in the sun, indulging in each and every sexual peccadillo assured of universal respect.... You go, girls! I'm setting you free. (2009: 387-8)

His conversion is so complete that it has everyone, including the Sons of the Rumour, worried. It also strains credibility. In this postmodern text, all characters and positions are presented ironically and there is more than a hint of mockery of the Shah's newly found feminist conviction. While Sons of the Rumour clearly exposes the contradictions inherent in misogyny, medieval and modern, Eastern and Western, it can hardly be argued that it does so from a contemporary feminist perspective. Moreover, the Shah's feminist conversion is not only unconvincing; it is also tainted by the novel's Orientalist reading of East-West relations.

Even before the Shah's conversion, Shahrazad is Western and modern. She also, rather strangely, seems to be Australian, using expressions such as such as 'check that out, mate' (2009: 60) and 'cool' (2009: 122). In a conversation between the Shah and Shahrazad when they go for a coffee (another anachronism) in the city of Merv, Shahrazad asks, '[why] can't a woman wear what she wants to wear in a civilised city? Guys wear what they want to wear. Why can't a woman do the same?' (2009: 126) The Shah's reply, that man's superiority is Allah's decree, sets up a contrast between Western, secular woman and Muslim man which runs through the novel. In a review of the novel James Ley argues that 'the personal difficulties between the Shah and Shahrazad are to a significant extent a consequence of their being a curiously modern couple' (2009: 16). This is only partially the case: while Shahrazad is 
undoubtedly modern, the Shah clings to a higher authority to justify his dominance over her. When she resists covering her hair he tells her that she is not a good woman, at the same time unwittingly echoing Said's argument regarding the Oriental veil which symbolises 'Muslim women's oppression and eroticism simultaneously' (Weber 2001: 125).

Shahrazad's challenge to the patriarchal order sets the scene for the Shah's re-education, and his conversion comes as a consequence of a dream of independent and emancipated women. Modern women, then, can be seen as saving him from misogyny, just as he, arguably, through his conversion becomes the saviour of Shahrazad and numerous other women from certain death. They thus exemplify the common trope of Western women's agency in the salvation of Eastern women and men which has become known as 'Feminist Orientalism'. 'Feminist Orientalism' confirms the superiority of modern Western women (Bahramitash 2005: 222). It is not an Eastern but a Western(ised) Shahrazad who claims control over her body, resists becoming a concubine and refuses to cover her hair. Roksana Bahramitash, in her article, 'The War on Terror, Feminist Orientalism and Orientalist Feminism', refers to Parvin Paidar's argument in Women in Public Spaces, Women and the Political Process in Twentieth Century Iran that one of the characteristics of 'Feminist Orientalism' is that it considers Oriental women as victims of patriarchy and not as agents of liberation and social transformation. Feminist Orientalism 'is blind to the ways in which women in the East resist and empower themselves. Therefore, Muslim women need saviors, i.e., their Western sisters' (Bahramitash 2005: 222). There are, in fact, no Iranian women as such in the novel. The text does not give voice to Eastern women; by transforming an Eastern woman into a Western one it shows that Eastern men need Western women for their re-education. Talpade Mohanty, in 'Under Western Eyes: Feminist Scholarship and Colonial Discourses', a critique of Western feminist discourse on women in the third world, argues that Western feminists are representing themselves as 'educated, modern [...] having control over their own bodies and sexualities, and the freedom to make their own 
decisions' (1991: 55). By contrast, non-Western women or women in the third world are represented by Western feminists as 'ignorant, poor, uneducated, tradition-bound, domestic, family-oriented, victimized, etc.' (Mohanty 1991: 56). It can be argued that the representation of women in Sons of the Rumour offers a perfect illustration of 'Feminist Orientalism' which, in Bahramitash's words, 'used women's rights as an excuse to legitimate their colonial presence and their modern version such as the current neo-conservatives who raise support for war in defence of women's rights' (2005: 221). By reinforcing popular stereotypes of Muslim women as victims of 'an inherent misogynism in Islamic tradition' (2005: 222) which can only be defeated through Western agency, the novel turns the story of the Shah and Shahrazad into a parable for our times: a confrontation between the East and the West over the control over women's bodies.

\section{Rewriting Cronulla}

In the Author's note at the end of his novel, Foster states that the writing was prompted by the Cronulla riot in 2005, at which he was present (2009: 423). His premise was that 'a major flashpoint now exists between (fundamentalist) Islamic man and (anti-Christian) secular Western woman' (2009: 424). In the novel, his contemporary character $\mathrm{Al}$ is an observer of the events in Cronulla on December 11, 2005. He remembers a Surf Club member looking for men of 'Middle Eastern appearance' asking him, a Jew, 'So, you a Muslim, pal? You still livin' the Dark ages?... I hate all Mustafas' (2009: 336). His own thoughts on the 'Leb hoons' are that '[t]hey want jihad but they'd like a slice of Aussie slut' (2009: 335). He goes on to reflect on the Cronulla memorial to the seven young women who were killed in the Bali bombing of 2002. Juxtaposing these events enables him to reinvent the Cronulla riots as a confrontation between the secular West and Islam: 
Mustafa from Punchabowl fears Allah. Allah says to him, in Bali - do Me a favour. Rid Me of these infidels. See how they fornicate and drink alcohol in the place where they worship the monkey? (2009: 359)

His conclusion is a deep pessimism: 'Mustafa from Punchabowl envies and fears modern Western debauchery. We fear and envy his Eternity and contempt for Death...And we can't defeat someone who has no fear of Death. Deep down, we're fucked and know it - but deep down' (2009: 375).

By representing the Cronulla riot, a confrontation between youth gangs from different ethnic backgrounds, as motivated by religion rather than race, the novel not only misrepresents the (mostly) Lebanese youths - Australia's Lebanese community is predominantly Christian it also turns the event (ugly enough, but for different reasons) into an argument in the Islamophobic discourse which has had a major resurgence since the attack on the World Trade Centre in 2001. As Lawrence Davidson writes in 'Islamophobia, The Israel Lobby and American Paranoia':

Islamophobia is a stereotyping of all Muslims (that is the stereotyping of over a billion human beings) as real or potential terrorists due to the alleged hateful and violent teachings of their religion. Islam is reduced to the concept of jihad and the concept of jihad is reduced to terror against the West. (2011: 90)

Or, as Said puts it in Orientalism: 'Islam comes to symbolize terror, devastation, the demonic, hordes of hated barbarians. For Europe, Islam was a lasting trauma' (2003: 59).

The racism on display in the Cronulla riots, with its echoes of a white Australia many believed had been laid to rest, has received extensive commentary since the event. As Greg Noble and Scott Poynting write, 'The Cronulla riots illustrate not simply the persistence of racism in Australia, but the complex interweaving of space and national belonging that has occurred over several years....it showed the ways the local and the national became entwined 
in practices of inclusion and exclusion that had dire consequences for Australians of migrant background' (2010: 499-500). Moreover, as Shakira Hussein and Scott Poynting have recently argued, the riots marked a 'a shift in the focus of racist Othering in Australia, from the 'Arab Other' to the 'Muslim Other'. Pointing out that the racism expressed in the riots has over the years since the event 'become normalised as an acceptable part of 'debate' in Australia', they argue that this is not a unique development but 'in line with trends in Europe and the US' (2017: 333). This normalisation of Islamophobia, producing race in the guise of religion, has become the face of contemporary racism, but one that allows its proponents to argue that to vilify unacceptable aspects of a faith is not racist: 'This slippage between racial and religious labels continues to characterise contemporary hate speech in Australia' (2017: 335). Sons of the Rumour, by representing the Cronulla riots as caused by irreconcilable systems of belief, and by linking them to the Bali bombing, can thus be read as an illustration of the normalcy of 'everyday' Islamophobia. Its construction of an 'us and them' based on elements of Islamic faith as opposed to Western secularism also echoes the slippage between race and religion which, in much of the commentary on the riots, led to the conflation of Lebanese and Muslim.

In an interview with Paul Sheehan, Foster said that his novel was 'not an attack on Islam... My favourite Islamic position is the sufi position. Islam is a very broad church. The Taliban are blowing up sufi shrines. It's an attractive form of Islam, noble. It's the one that I like'. 'It [The Arabian Nights] is a strange frame tale', he added. 'It's a sufi parable. It equates sex and death. I think sex is death. Death is the price you pay for sex' (Sheehan 2009: 26-27). In the novel, Sufism, as represented by the Sons of the Rumour, provides what philosophical wisdom is available in a world of fear, violence and superstition. In the contemporary world, Al Morrisey, searching for spiritual guidance among the flotsam and jetsam of Western and Eastern belief systems, has also found solace in Sufi mysticism. However, the 'broad church' of Islam does not, in this novel, present any other alternatives to the misogyny and terror, which, 
to the Shah as well as to 'Mustafa from Punchabowl', are direct functions of the Muslim faith. And as for Al, modern, secular man, letting go of the misogyny which defined his masculinity has little to do with spiritual enlightenment but rather signals his defeat at the hands of his more resourceful wife.

Sons of the Rumour offers no ringing endorsement of the opponents of Muslim fundamentalism. The Cronulla life-savers are ill-informed thugs, Shahrazad is vain and vulgar, even the Sons of the Rumour act out of selfish as well as spiritual motivations. However, for all the complexity of its historical, religious and mythical universe, for all the postmodern inventiveness and instability of its story-telling, it would be hard to argue that it does anything but harden and exaggerate stereotypes of Islam and Muslims which have found such fertile ground in the West in recent decades. Scholars researching the origins and development of One Thousand and One Nights, and particularly its translation for a European readership in the $18^{\text {th }}$ century, comment on its popularity as a function of the West's abiding taste for a sensual and violent Oriental 'Other'. By recreating the familiar structure of One Thousand and One Nights for a contemporary Western understanding of and taste for Orientalist material, Foster's novel does little to dispel the fear and fascination associated with the mythical East in the Western imagination. 


\section{Works Cited}

Al-Olaqi, F.M.T.S., 2012. The Influence of the Arabian Nights on English Literature: A Selective Study. European Journal of Social Sciences, 31(3), 384-396.

Bahramitash, R., 2005. The War on Terror, Feminist Orientalism and Orientalist Feminism: Case Studies of Two North American Bestsellers. Critique: Critical Middle Eastern Studies, 14 (2), 221-235.

Bloch, R.H., 1991. Medieval Misogyny and the Invention of Western Romantic Love. Chicago: University of Chicago Press.

Davidson, L., 2011. Islamophobia, the Israel Lobby and American Paranoia: Letter from America. Holy Land Studies: A Multidisciplinary Journal, 10 (1), 87-95.

Foster, D., 2009. Sons of the Rumour. Sydney: Picador.

Gardiner, J.K., 2007. Love. In: M. Flood, J. K. Gardiner, B. Pease, and K. Pringle, eds. International Encyclopaedia of Men and Masculinities. London: Routledge, 369-370.

Hussein, S, \& Poynting, S., 2017, We're Not Multicultural, but ..., Journal Of Intercultural Studies, 38 (3), 333-348.

Irwin, R., 2009. The Arabian Nights: A Companion. London : I.B. Tauri.

Kabbani, R., 1994. Imperial Fictions: Europe's Myths of Orient. London: Pandora.

Lever, S., 2013. Strange and Beautiful: David Foster's Sons of the Rumour. Westerly, 58 (2), 85-100.

Ley, J., 2009. A Town Called Merv: Brilliant writing from the quixotic David Foster. Australian Book Review, 316, 15-16. 
Marzolph, U., 2006a. The 'Arabian Nights' in Comparative Folk Narrative Research. In: Y. Yamanaka and T. Nishio, eds. The Arabian Nights and Orientalism: Perspectives from East \& West. London: I.B. Tauris, 3-24.

Marzolph, U., 2006b. The Arabian Nights Reader. Detroit: Wayne State UP.

Marzolph, U., 2004, The Persian Nights: Links between the Arabian Nights and Persian Culture. Fabula, 45 (3-4), 275-293.

Mohanty, C.T., 1991, Under Western Eyes: Feminist Scholarship and Colonial Discourses. In: C.T. Mohanty, A. Russo, and L. Torres, eds. Third World Women and the Politics of Feminism. Bloomington: Indiana UP, 51-80.

Noble, G, \& Poynting, S., 2010, White Lines: The Intercultural Politics of Everyday Movement in Social Spaces. Journal of Intercultural Studies, 31 (5): 489-505.

Pellat, Ch., 1985, Alf Layla Wa Layla. Encyclopaedia Iranica, 1(8), 831-835.

Said, E. W., 2003. Orientalism. London: Penguin.

Sheehan, P., 2009. Classic Heroine Hits the Beach: David Foster Talks to Paul Sheehan. The Sydney Morning Herald, 31 Oct, 26.

Sornig, D., 2009. Arabian Tales, Suburban Spice. The Age, 12 December, 29.

Weber, Ch., 2001. Unveiling Scheherazade: Feminist Orientalism in the International Alliance of Women, 1911-1950. Feminist Studies 27(1), 125- 57. 